\title{
INVESTIGATING THE CURRENT CONDITIONS AND DIFFICULTIES THAT JUNIOR HIGH SCHOOL STUDENTS IN CAN THO CITY HAVE WHEN ENGAGED IN EXTRACURRICULAR SPORT ACTIVITIES
}

\author{
Tran Quang Nhut ${ }^{1}$, \\ Nguyen Quang Vinh ${ }^{2 i}$ \\ ${ }^{1}$ Thoi Lai Junior High School, \\ Can Tho City, \\ Vietnam
} ${ }^{2} \mathrm{Ho}$ Chi Minh City University of Physical Education and Sport, Ho Chi Minh City, Vietnam

\begin{abstract}
:
The paper employed conventional scientific research methods such as synthesis and analysis of documents and questionnaires to investigate the current conditions in terms of facilities, ground yards, management staff, trainers, and guides to ensure extracurricular sport activities (ESA) for high school students in Can Tho City, Vietnam. The results show that the curriculum is implemented properly in accordance with the regulations of the Ministry of Education and Training. The facilities, training grounds, and teaching staff also ensure the ESA for the students. Moreover, the paper also examined challenges that junior high school students faced when participating in ESA. According to the results, the lack of concern from students' parents, the high cost of training, and the limited time available for training physical sessions are the main difficulties preventing students from participating in ESA.
\end{abstract}

Keywords: current conditions, extracurricular sport activities (ESA), high school students, challenges, Can Tho city

\section{Introduction}

Physical education (PE) and sports activities at school are not only essential components of the education system but also an important component of the sports foundation and the general public. Notably, PE and school sports are the intersection of academic and physical education, the foundation of physical education and sports development. As a

'Correspondence: email vinhqn@upes.edu.vn 
result, the government is more concerned about investing in and developing PE at schools. More notably, PE includes two main activities: intra-curricular and ESA. Along with the intra-curricular physical classes, extracurricular sports serve an essential role in enhancing students' health, fitness, mental strength, and excellent personality. In addition, they are voluntary sports activities that take place in the form of a guide or selfpractice, generally outside of school hours, and are suited to the interests, gender personality, age, and health of students.

It is needless to say that one of the most significant components of schooling education is extracurricular activities (or educational activities outside of class time). The activities are intended to promote intra-curricular, develop good personalities, and boost students' competencies and creativity. Hence, the content of extracurricular education is quite varied, as shown by social activities, the arts, physical sessions, school trips, work, scientific research, and so on. The activities allow students to apply and deepen their academic knowledge in the real world and also raise interest in extracurricular learning. Extracurricular education is frequently provided by specific people (subject teachers, head teachers) or reputable organizations (Communist Youth Union, Student Union, etc.).

Facilities, staff, and curriculum are three elements that determine the effectiveness of PE and ESA at junior high schools in Can Tho City. Aside from the above elements, there are several obstacles that hamper the development of ESA. Hence, the authors decided to conduct this study in the hopes of building a proper foundation of feasible solutions for advancing extracurricular activities for junior high school students in Can Tho City: "Investigating the current conditions and difficulties that junior high school students in Can Tho City have when engaged in extracurricular sport activities"

The purpose of the writing is to provide accurate, scientific, and comprehensive information about the current conditions as well as the difficulties that students usually encounter when participating in ESA of junior high school in Can Tho city.

\section{Research methods}

Research methods: document synthesis and analysis, interviewing, mathematical and statistical method.

\subsection{Participants}

- 15 experts, specialists, lecturers, and managers; 7 PE teachers in Can Tho City.

- 491 students (256 schoolboys and 235 schoolgirls), grade 7 of Thoi Lai Junior High School in Thoi Lai town, Thoi Lai district, Can Tho City. 


\section{Research results}

\subsection{The current conditions to ensure extracurricular sport activities for students in Can} Tho City junior high school

In order to assess the current conditions of holding extracurricular activities, the writers conducted a survey of PE teachers and administrators at Thoi Lai Junior High School. The results obtained from the survey are presented in tables 1, 2, 3 .

\subsection{About the physical education programs}

The PE curriculum for seventh grade has closely adhered to the Ministry of Education and Training's framework program, which includes particular contents as shown in Table 1 .

Table 1: PE curriculum for seventh grade at junior high schools in Can Tho City

\begin{tabular}{lc}
\hline Contents & Duration of time \\
\hline Chapter 1: Benefits and effects of PE and sports & $2(2,0,0)$ \\
\hline Chapter 2: Practice lineup & $8(0,7,1)$ \\
\hline Chapter 3: General development exercise & $6(0,5,1)$ \\
\hline Chapter 4: short distance running (fast running) & $10(0,9,1)$ \\
\hline Chapter 5: Endurance running & $6(0,5,1)$ \\
\hline Chapter 6: High jump, long jump (jump up) & $12(0,11,1)$ \\
\hline Chapter 7: Shuttlecock Kicking & $6(0,5,1)$ \\
\hline Chapter 8: Elective sports & $12(0,11,1)$ \\
\hline Review, test for semester 1 and 2; test and evaluate, rate physical strength. & $8(0,4,4)$ \\
\hline Total & $70(2,57,11)$ \\
\hline
\end{tabular}

The results in Table 1 show that the PE curriculum for one year: 37 weeks (70 periods), of which the first semester 1: 19 weeks (36 hours) and the second one: 18 weeks (34 hours); with 50 compulsory classes, 12 optional classes and 08 left ones for reviewing and testing.

\subsection{Teaching staff}

Table 2 summarizes the detail of the demographic information of the teaching staff engaging in ESA at one junior high school in Can Tho City.

Table 2: Demographic statistics of teachers participating in ESA at junior high schools in Can Tho City

\begin{tabular}{llcc}
\hline \multirow{2}{*}{ Content } & \multicolumn{2}{c}{$\begin{array}{c}\text { Thoi Lai Junior } \\
\text { High school }\end{array}$} \\
\cline { 2 - 4 } & \multicolumn{2}{c}{$\begin{array}{c}\text { Percentage } \\
\text { Total number of students }\end{array}$} & \multicolumn{2}{c}{$0,41 \%$} \\
\hline Percentage of teaching staff/number of students & 7 & 100.0 \\
\hline \multirow{2}{*}{ Sex } & Male & 0 & 00 \\
\cline { 2 - 4 } & Female & 2 & 28,6 \\
\hline Age & $<30$ & 2
\end{tabular}




\begin{tabular}{|c|c|c|c|}
\hline & $30-40$ & 5 & 71,4 \\
\hline & $>40$ & 0 & 00 \\
\hline \multirow[t]{3}{*}{ Qualification } & College & 0 & 00 \\
\hline & University & 7 & 100.0 \\
\hline & Postgraduate & 0 & 00 \\
\hline \multirow[t]{2}{*}{ Teacher } & Visiting teacher (part-time) & 0 & 00 \\
\hline & Full-time teacher & 7 & 100.0 \\
\hline \multirow[t]{4}{*}{ Trained specialty } & Physical education & 7 & 100.0 \\
\hline & Sports Coaching & 0 & 00 \\
\hline & Sports management & 0 & 00 \\
\hline & Biomedical physical education and sports & 0 & 00 \\
\hline \multirow[t]{2}{*}{ Teaching content } & Appropriate & 7 & 100.0 \\
\hline & Inappropriate & 0 & 00 \\
\hline \multirow{5}{*}{$\begin{array}{l}\text { Seniority level } \\
\text { (years of experience) }\end{array}$} & $<5$ & 2 & 28,6 \\
\hline & $6-10$ & 2 & 28,6 \\
\hline & $11-15$ & 2 & 28,6 \\
\hline & $16-20$ & 1 & 14,3 \\
\hline & $>20$ & 0 & 00 \\
\hline Total & & 7 & 100.0 \\
\hline
\end{tabular}

Surprisingly, Table 2 shows that $100 \%$ of PE teachers are men who work as full-time trainers and have university degrees in physical education, therefore their teaching material is consistent with their major. In terms of age, the majority of the teachers are between 30 and 40 years old ( 5 teachers), accounting for $71.4 \%$, and there are 02 teachers under 30 years old, accounting for $28.6 \%$. In terms of teaching experience, each seniority has two teachers, accounting for $28.6 \%$, except for 16 to 20 years has one teacher, accounting for $14.3 \%$.

\subsection{Facilities}

Statistical results of facilities for extra-curricular activities at junior high schools in Can Tho City are presented in Table 3.

Table 3: The current facilities for extracurricular sport activities at junior high schools in Can Tho City

\begin{tabular}{lccc}
\hline Facilities & Quantity & Area $\left.\mathbf{( m}^{\mathbf{2}}\right)$ & Quality \\
\hline Multi-function gym & 1 & 1008 & Good \\
\hline Artificial grass soccer field & - & - & - \\
\hline Natural grass soccer field & 1 & 1400 & Good \\
\hline Volleyball court & 2 & 360 & Good \\
\hline Basketball court & 1 & 500 & Good \\
\hline Badminton court & 2 & 400 & Good \\
\hline Ping pong house & 2 & 96 & Good \\
\hline Running track 100m - 200m & 4 & 600 & Good \\
\hline Takeoff board for high jump and long jump & 1 & 150 & Good \\
\hline Shuttlecock court & 2 & 400 & Good \\
\hline
\end{tabular}


INVESTIGATING THE CURRENT CONDITIONS AND DIFFICULTIES THAT JUNIOR HIGH SCHOOL

STUDENTS IN CAN THO CITY HAVE WHEN ENGAGED IN EXTRACURRICULAR SPORT ACTIVITIES

\begin{tabular}{lccc}
\hline \hline Outdoor training ground (schoolyard) & 1 & 2574 & Good \\
\hline Total area & & 7.488 & \\
\hline Total students & 1692 & \\
\hline Rate of students $/ \mathrm{m}^{2}$ & 4.43 & \\
\hline
\end{tabular}

Table 3 shows that the total area of facilities for ESA at Can Tho City's junior high schools is 7,488 $\mathrm{m}^{2}$, including 01 multi-function gym $\left(1008 \mathrm{~m}^{2}\right), 01$ natural grass soccer field (1400 $\left.\mathrm{m}^{2}\right), 2$ volleyball courts $\left(320 \mathrm{~m}^{2}\right), 01$ basketball court $\left(500 \mathrm{~m}^{2}\right), 02$ badminton courts $(400$ $\left.\mathrm{m}^{2}\right), 02$ ping pong houses $\left(96 \mathrm{~m}^{2}\right), 04$ running tracks $100 \mathrm{~m}-200 \mathrm{~m}\left(600 \mathrm{~m}^{2}\right), 01$ takeoff board for high jump and long jump $\left(150 \mathrm{~m}^{2}\right), 02$ shuttlecock courts $\left(400 \mathrm{~m}^{2}\right)$, outdoor training ground $\left(2574 \mathrm{~m}^{2}\right)$; besides, the rate of students $/ \mathrm{m}^{2}$ is $4.43 \mathrm{~m} 2$.

\subsection{Difficulties and obstacles that PE teachers and seventh-grade students at junior high schools in Can Tho City have to face when participating in ESA}

Two steps were employed to define the criteria for evaluating the challenges experienced by seventh-grade students in Can Tho City's junior high schools when engaging in ESA:

Step 1: Consult experts; then based on the reality and the research's scope to determine the criteria

Step 2: Make polls, prepare questionnaires, and interview 15 persons in Can Tho province, including 04 managers (administrators), 9 specialists, and 02 PE experts, with two responses: agreeing and disagreeing. Finally, choose 13 criteria based on the interview findings to measure the difficulties that junior high school students face when engaging in extracurricular sports:

Objective obstacles (8 items): the content of sports programs, training forms, facilities, sporting grounds, instruments, professional qualifications of trainers, practicing time, lack of parents' support and the school board's concern, and training costs.

Subjective obstacles ( 5 items): lack of interest in exercise and sports activities, lack of abilities for exercise and sports, fear of pain or injury, insufficient practice time, low stamina.

To find out the obstacles and difficulties faced by junior high school students when participating in extra-curricular sports, the authors surveyed 491 seventh-grade students in Can Tho City and divided their responses into five levels: (1) Very unaffected, (2) unaffected, (3) normal, (4) affected, (5) very affected, as shown in Table 4.

Table 4: Survey results on difficulties of students when participating in extracurricular sports

\begin{tabular}{llcc}
\hline \multirow{2}{*}{ Difficulties } & \multicolumn{2}{c}{ Survey results } \\
\cline { 3 - 4 } & & $\bar{X}$ & $\mathrm{~S}$ \\
\hline & Objective difficulties & 3.61 & \\
\hline 1 & Content of program & 3.48 & 0.67 \\
\hline 2 & Form of training & 3.69 & 0.56 \\
\hline 3 & Facilities, yards, instruments & 3.63 & 0.56 \\
\hline 4 & Professional qualifications of coaches, guides & 3.66 & 0.56 \\
\hline
\end{tabular}


INVESTIGATING THE CURRENT CONDITIONS AND DIFFICULTIES THAT JUNIOR HIGH SCHOOL STUDENTS IN CAN THO CITY HAVE WHEN ENGAGED IN EXTRACURRICULAR SPORT ACTIVITIES

\begin{tabular}{clcc}
\hline \hline 5 & Practicing time & 3.47 & 0.50 \\
\hline 6 & Parents' support and concern & 3.84 & 0.50 \\
\hline 7 & The school principal Board's support and concern & 3.74 & 0.55 \\
\hline 8 & Training costs & 3.38 & 0.49 \\
\hline & Subjective difficulties & $\mathbf{2 . 4 2}$ & \\
\hline 9 & Lack of interest in exercise and sports activities & 2.3 & 0.64 \\
\hline 10 & Lack of abilities for exercise and sports & 2.39 & 0.68 \\
\hline 11 & Fear of pain or injury & 2.45 & 0.68 \\
\hline 12 & Insufficient practice time & 2.52 & 0.70 \\
\hline 13 & Low stamina & 2.42 & 0.50 \\
\hline
\end{tabular}

\subsection{Objective difficulties}

On the one hand, table 4 shows that students are rated on average 3.61 points (between normal and affected), with the item requesting parents' support and concern having the highest influence of 3.84 points (near the affected level) and the training cost having the lowest influence of 3.38 points (near the normal level); the remaining factors range from 3.47 to 3.74 points (between normal and affected). Chart 1 depicts the survey results on objective obstacles junior high school students normally face when participating in extracurricular activities.

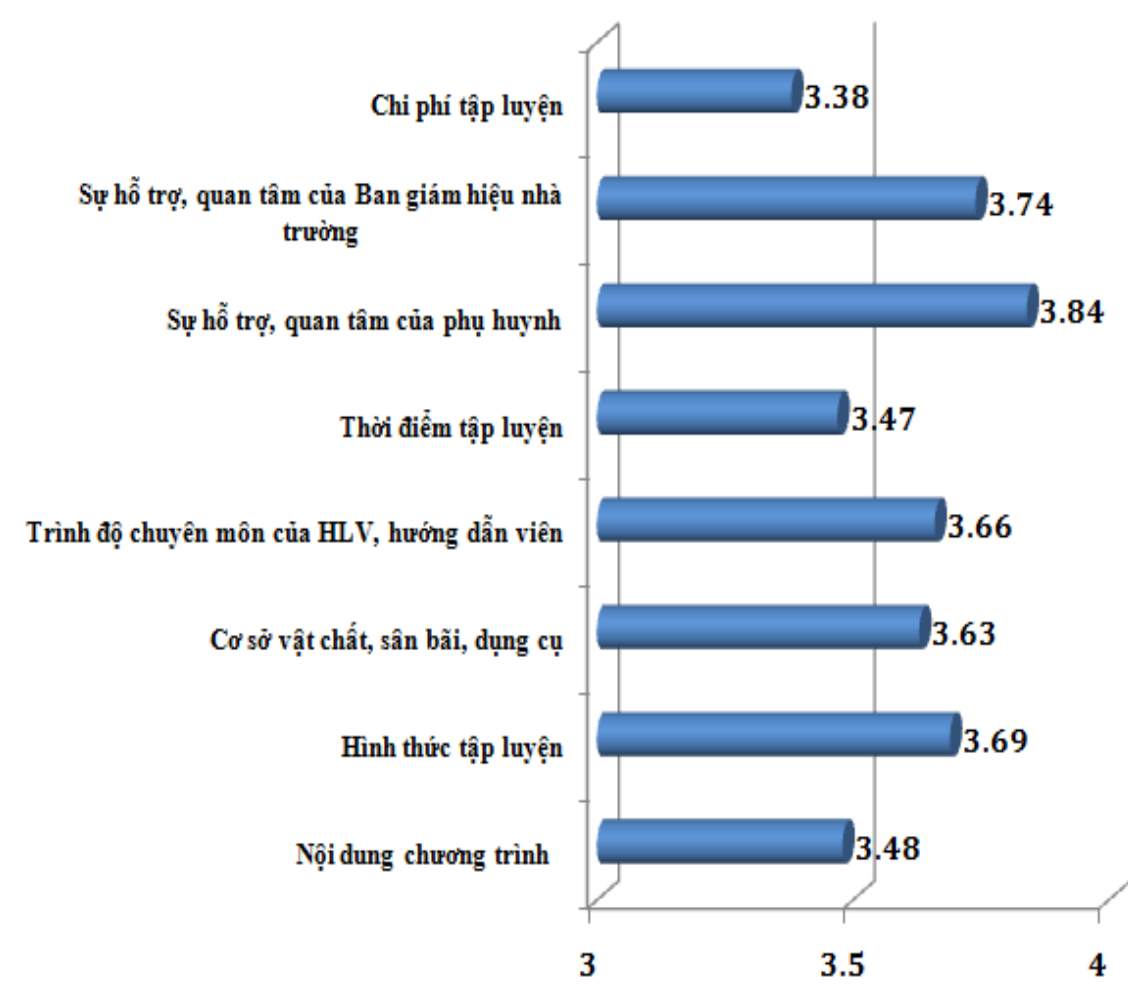

Chart 1: Survey results on objective obstacles affecting junior high school students engaging in extracurricular activities 


\subsection{Subjective difficulties}

On the other hand, table 4 shows that students rated an average of 2.42 points (near normal and unaffected level), with inadequate practice time having the highest influence 2.52 points (near normal and unaffected level) and the lack of interest in exercise and sports having the lowest level of influence at 2.30 points (near unaffected level); the remaining factors ranged from 2.39 to 2.45 points (between normal and unaffected level). Chart 2 illustrates the survey results on subjective obstacles that junior high school students normally face when joining extracurricular activities.

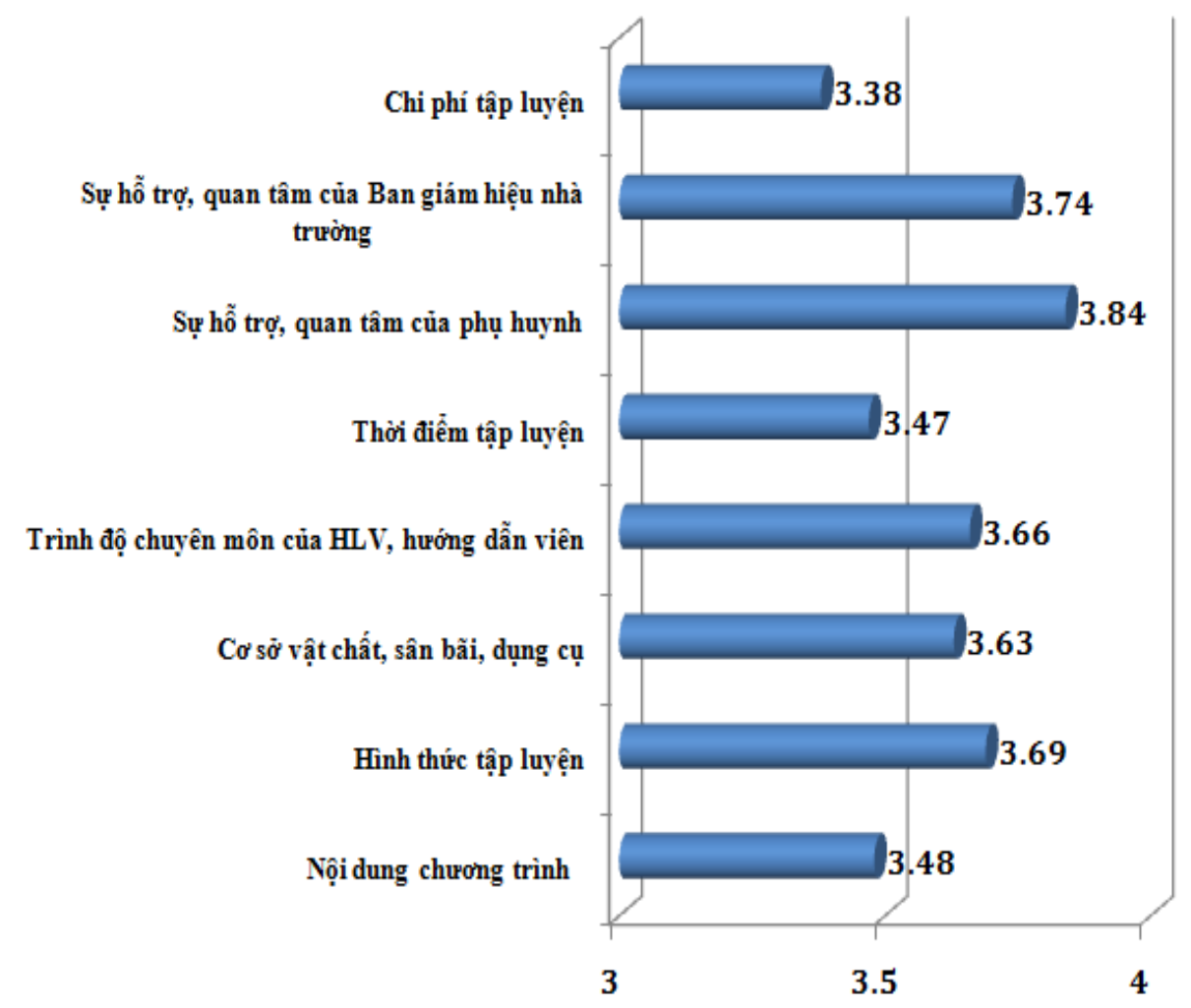

Chart 2: Survey results on subjective obstacles affecting junior high school students engaging in extracurricular activities

\section{Conclusion}

About the current conditions, the 70-hour PE curriculum is now being used to ensure extracurricular activities for junior high school pupils in Can Tho City (50 compulsory classes, 12 optional classes, and 8 left ones for reviewing and testing). About teaching staff, all of them are male, have a bachelor's degree in physical education, and work fulltime; besides, the majority of them are between the ages of 30 and 40 and have fewer than 15 years of experience. About facilities, the rate of students $/ \mathrm{m}^{2}$ is $4.43 \mathrm{~m}^{2}$. In addition, multi-function gyms, natural grass soccer fields, volleyball courts, basketball courts, badminton courts, ping pong houses, $100 \mathrm{~m}-200 \mathrm{~m}$ running tracks, takeoff boards for high jump and long jump, shuttlecock courts, and outdoor training grounds are among the school's extracurricular activities facilities, which cover a total area of $7,488 \mathrm{~m}^{2}$. 
Thirteen criteria have been identified for evaluating students' difficulties and obstacles when participating in ESA. The survey results show that the most significant objective difficulty affecting students' extracurricular activities is a lack of parental support and concern, whereas training costs have the least impact; on the other hand, the most significant subjective difficulty affecting students' extracurricular activities is insufficient practice time while lacking interest in sports activities has the least impact.

\section{Conflict of Interest Statement}

The authors declare no conflicts of interests.

\section{About the Author}

Tran Quang Nhut Thoi has been principal of Lai Junior High School, Can Tho City, Vietnam, but his major is Physical Education.

Nguyen Quang Vinh is Associate Professor who has been Head of Academic Affairs at Ho Chi Minh University of Physical Education and Sports. His research interests include physical education, teachers' beliefs and PE curriculum planning.

\section{References}

The Central Committee of the Communist Party of Vietnam (2011), Resolution No. 08NQ/TW, December 1, 2011, on strengthening the leadership of the Party, creating strong development in physical education, sports by 2020.

Ministry of Culture, Sports and Tourism (2019), Circular No. 01/2019/TT-BVHTTDL, dated January 17, 2019, stipulating the assessment of mass physical training and sports movements.

Ministry of Education and Training (2008), Decision No. 72/2008/QD-BGDDT dated December 23, 2008, on promulgating Regulations on organization of extracurricular sport activities for pupils and students.

Tran Kim Cuong (2008), "The real situation of extracurricular sports practice in schools in Ninh Binh province", Journal of Sports and Science (6), Institute of Sports and Science, Hanoi, p.56-60.

Tran Huu Hung (2015), Research on improving the form and content of physical training exercises for junior high school students in the Gia Lai - Kon Tum highland area, Doctoral thesis in Education, Institute of Science and physical education and sports.

Le Van Lam - Pham Xuan Thanh (2008), School physical training and sports curriculum, Sports Publishing House, Hanoi.

Prime Minister (2015), Decree No. 11/2015/ND-CP, January 31, 2015 Regulations on physical education and sports activities in schools.

Hoang Trong, Chu Nguyen Mong Ngoc (2008), Analysis of research data with SPSS, Hong Duc Publishing House. 
Tran Quang Nhut, Nguyen Quang Vinh

INVESTIGATING THE CURRENT CONDITIONS AND DIFFICULTIES THAT JUNIOR HIGH SCHOOL STUDENTS IN CAN THO CITY HAVE WHEN ENGAGED IN EXTRACURRICULAR SPORT ACTIVITIES

Creative Commons licensing terms

Authors will retain the copyright of their published articles agreeing that a Creative Commons Attribution 4.0 International License (CC BY 4.0) terms will be applied to their work. Under the terms of this license, no permission is required from the author(s) or publisher for members of the community to copy, distribute, transmit or adapt the article content, providing a proper, prominent and unambiguous attribution to the authors in a manner that makes clear that the materials are being reused under permission of a Creative Commons License. Views, opinions and conclusions expressed in this research article are views, opinions and conclusions of the author(s). Open Access Publishing Group and European Journal of Physical Education and Sport Science shall not be responsible or answerable for any loss, damage or liability caused in relation to/arising out of conflict of interests, copyright violations and inappropriate or inaccurate use of any kind content related or integrated on the research work. All the published works are meeting the Open Access Publishing requirements and can be freely accessed, shared, modified, distributed and used in educational, commercial and non-commercial purposes under a Creative Commons attribution 4.0 International License (CC BY 4.0). 